\title{
Wheatgrass - A Wonder Herb against Periodontal Pathogens: An In Vitro Study
}

\author{
G. A. Babitha, Mansi Bansal, Shobha Prakash \\ Department of Periodontics, College of Dental Sciences, Davanagere, Karnataka, India
}

Email for correspondence: mansi.bansal17@gmail.com

\begin{abstract}
Background: Wheatgrass (Triticum aestivum) is a commonly found herb in India. Given its medicinal capability, it has found application in the treatment of gingivitis and periodontal diseases. Aims and Objectives: The aims of the study were to find whether wheatgrass powder is efficacious against the growth of periodontal pathogens; Porphyromonas gingivalis (Pg), Prevotella intermedia, Tannerella forsythia, and Fusobacterium nucleatum and also to quantify the amount of wheatgrass powder needed for its bactericidal activity against periodontal pathogens using tube dilution test. Materials and Methods: Pure concentrated form of commercially available wheatgrass powder was obtained and its minimum inhibitory concentration against periodontal pathogens was estimated using serial dilutions of the agent by the tube dilution method. Results: Minimum inhibitory concentration of wheatgrass powder was found at $3.12 \mathrm{mg} / \mathrm{ml}$ for Pg, whereas it was significantly lower for other organisms. Conclusions: Wheatgrass shows a lot of promise in the field of alternative medicine, especially for applications in periodontitis and possibly other oral infections. Further studies are recommended for assessing its use both in clinical and field settings.
\end{abstract}

Key words: Minimum inhibitory concentration, periodontal pathogens, periodontitis, tube dilution method, wheatgrass (Triticum aestivum)

\section{INTRODUCTION}

Periodontal disease is a chronic inflammatory disease, affecting structures around the teeth. It causes inflammation of the periodontal tissues resulting in clinical attachmentloss, alveolar bone loss, and periodontal pocketing. Global epidemiological data recognized periodontal disease to be one of the most common and burdensome on oral diseases. The proportion of the population above the age of 15 years with periodontitis could be $80-90 \% .^{[1]}$ Periodontal therapy goal is to reduce or eliminate the subgingival microorganisms and restore periodontal health.

Antibiotics (local and systemic) and surgical procedures have been used as an adjunct to antiinfective therapy for the elimination of pathogenic

Quick Response Code Article Info:

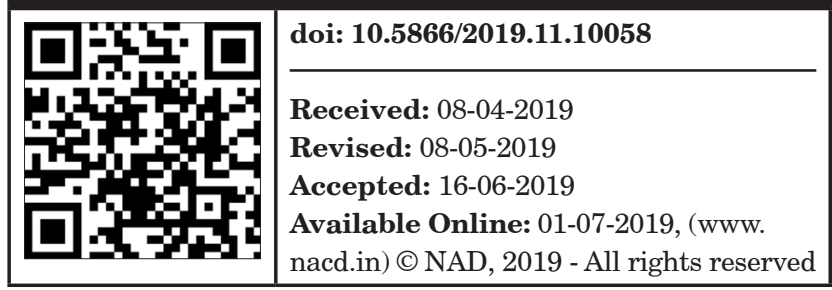

subgingival microflora. Since prolonged use of antibiotics poses the threat of developing resistant strains, there has been rising interest in the development of other classes of antimicrobials for the control of infection.

Wheatgrass (Triticum aestivum) is a commonly found herb in India that refers to young grass of the common wheat plant belonging to Poaceae family. It has gained traction in scientific research as a "functional food" due to its antiaging, anticarcinogenic, laxative, antioxidant, antiinflammatory, antibacterial, and healing properties.

Healing effect of wheatgrass is attributed to chlorophyll which acts on fibroblasts and assists in wound and injury healing both inside the body and on the skin and resulting in a "rapidly increased growth rate" and marked increase in the rate of cell division.

Given medicinal capability of wheatgrass, it has found application in the treatment of gingivitis and periodontal diseases.

This is the first study to

- Identify the efficacy of wheatgrass powder against the growth of periodontal pathogens; 
Porphyromonas gingivalis (Pg), Prevotella intermedia (Pi), Tannerella forsythia (Tf), and Fusobacterium nucleatum (Fn).

- Quantify the amount of wheatgrass powder needed for its bactericidal activity against periodontal pathogens using tube dilution test.

\section{MATERIALS AND METHODS}

Pure concentrated form of commercially available wheatgrass powder was obtained and its minimum inhibitory concentration against periodontal pathogens was estimated using serial dilutions of the agent by the tube dilution method.

\section{Tube Dilution Method}

Nine dilutions of wheatgrass powder were done with thioglycollate broth. In the initial tube, $20 \mu \mathrm{L}$ of powder was added into the $380 \mu \mathrm{L}$ of thioglycollate broth. For dilutions, $200 \mu \mathrm{L}$ of thioglycollate broth was added into the next nine tubes separately. Then, from the initial tube, $200 \mu \mathrm{L}$ was transferred to the first tube containing $200 \mu \mathrm{L}$ of thioglycollate broth. This was considered as $10^{-1}$ dilution. From $10^{-1}$ diluted tube, $200 \mu \mathrm{L}$ was transferred to the second tube to make $10^{-2}$ dilution. The serial dilution was repeated up to $10^{-9}$ dilution for each drug. From the maintained stock cultures of required organisms, $5 \mu \mathrm{L}$ was taken and added into $2 \mathrm{ml}$ of thioglycollate broth. In each serially diluted tube, $200 \mu \mathrm{L}$ of above culture suspension was added. The tubes were incubated for $48-72 \mathrm{~h}$ in anaerobic jar at $37^{\circ} \mathrm{C}$ and observed for turbidity [Figure 1].

\section{RESULTS}

In the present study, all four periodontal pathogens, namely, $\mathrm{Pg}, \mathrm{Pi}, \mathrm{Fn}$, and Tf were sensitive to pure wheatgrass powder.

$\mathrm{Pi}$ and Tf were sensitive until $0.8 \mathrm{mg} / \mathrm{ml}$ dilution and showed resistance to further dilution. Fn was sensitive until $1.6 \mathrm{mg} / \mathrm{ml}$ dilution and showed resistance to further dilution. $\mathrm{Pg}$ was sensitive until $3.12 \mathrm{mg} / \mathrm{ml}$ dilution and showed resistance to further dilution. $\mathrm{Pi}$ and $\mathrm{Tf}$ were found to be more sensitive than Fn and Pg [Table 1].

\section{DISCUSSION}

Periodontitis is an inflammatory disease of supporting tissues of teeth caused by specific microorganisms or groups of specific microorganisms, resulting in progressivedestruction of the periodontal ligament and alveolar bone with periodontal pocket formation, gingival recession, or both. Successful periodontal treatment requires suppression or elimination of the subgingival periodontal pathogens. Antimicrobial agents attempt to directly reduce the pocket microflora when applied as an adjunct to mechanical debridement.

Wheatgrass is the mature shoot of T. aestivum Linn. belonging to the family Gramineae. Triticum is a genus of annual and biennial grasses, yielding various types of wheat, native to Southwest Asia. In general, 15-20 species are recognized of which, 8 have been reported to occur in India. The use of wheatgrass ( $T$. aestivum) herb as medicine has been practiced worldwide since ancient days. Wheatgrass has a long history and is widely used as a health food supplement.

Wheatgrass juice is rich in Vitamin A, B complex, C, and E. ${ }^{[2]}$ It contains plethora of

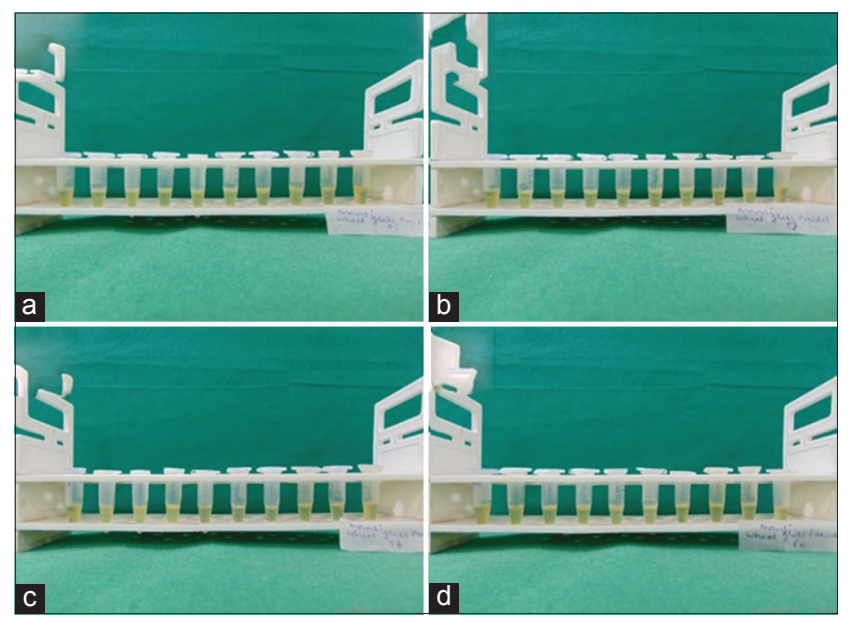

Figure 1: Serial dilutions of wheatgrass powder; (a) Prevotella intermedia, (b) Porphyromonas gingivalis, (c) Tannerella forsythia, (d) Fusobacterium nucleatum

\begin{tabular}{lcccccccccc} 
Table 1: Sensitivity of the periodontal pathogens to wheatgrass & \multicolumn{1}{l}{} \\
Wheatgrass extract & $\mathbf{1 0 0} \mathbf{~} \mathbf{m} / \mathbf{m l}$ & $\mathbf{5 0}$ & $\mathbf{2 5}$ & $\mathbf{1 2 . 5}$ & $\mathbf{6 . 2 5}$ & $\mathbf{3 . 1 2}$ & $\mathbf{1 . 6}$ & $\mathbf{0 . 8}$ & $\mathbf{0 . 4}$ & $\mathbf{0 . 2}$ \\
\hline Porphyromonas gingivalis & $\mathrm{S}$ & $\mathrm{S}$ & $\mathrm{S}$ & $\mathrm{S}$ & $\mathrm{S}$ & $\mathrm{S}$ & $\mathrm{R}$ & $\mathrm{R}$ & $\mathrm{R}$ & $\mathrm{R}$ \\
Prevotella intermedia & $\mathrm{S}$ & $\mathrm{S}$ & $\mathrm{S}$ & $\mathrm{S}$ & $\mathrm{S}$ & $\mathrm{S}$ & $\mathrm{S}$ & $\mathrm{S}$ & $\mathrm{R}$ & $\mathrm{R}$ \\
Fusobacterium nucleatum & $\mathrm{S}$ & $\mathrm{S}$ & $\mathrm{S}$ & $\mathrm{S}$ & $\mathrm{S}$ & $\mathrm{S}$ & $\mathrm{S}$ & $\mathrm{R}$ & $\mathrm{R}$ & $\mathrm{R}$ \\
Tannerella forsythia & $\mathrm{S}$ & $\mathrm{S}$ & $\mathrm{S}$ & $\mathrm{S}$ & $\mathrm{S}$ & $\mathrm{S}$ & $\mathrm{S}$ & $\mathrm{S}$ & $\mathrm{R}$ & $\mathrm{R}$ \\
\hline
\end{tabular}

S: Sensitive, R: Resistant. Interpretation: Prevotella intermedia and Tannerella forsythia > Fusobacterium nucleatum > Porphyromonas gingivalis 
minerals such as calcium, phosphate, zinc, boron, molybdenum, alkaline earth metals, potassium, and selenium. ${ }^{[3]}$ It is also called as "green blood" due to its high content of chlorophyll, which bears a structural similarity to hemoglobin and this results in high oxygen supply to all the body tissues.

Apart from these, it also contains antioxidant enzymes, superoxide dismutase and cytochrome oxidase that have the potential to convert reactive oxygen species to hydrogen peroxide and oxygen molecule. It also has the ability to inhibit oxidative DNA damage. ${ }^{[4]}$ The three most important effects of wheatgrass on human body are blood purification, liver detoxification, and colon cleansing. It has been used and found effective for the treatment of minor ailments and serious life-threatening issues like ulcerative colitis and has also been used as a preventive dietary supplement. ${ }^{[5,6]}$

Wheatgrass acts as a topical anti-inflammatory immunomodulator, substance $\mathrm{P}$ inhibitor, topical hemostatic agent, and stimulant of fibroblastic activity, with a wide range of healing properties. It also acts as a natural antibiotic that is bactericidal for pathogens that cause tooth caries, halitosis, and periodontal disease.

According to a study by Rajpurohit et al., wheatgrass extract demonstrated antimicrobial activity against Streptococcus mutans and Lactobacillus species at a minimum inhibitory concentration of $5 \%$ and $1.25 \%$ of the extract in ethanol for S. mutans and Lactobacillus spp., respectively. Since no direct assays have been performed on oral biofilms, current research was carried out with the aim of finding the efficacy of wheatgrass powder against periodontal pathogens using tube dilution method wherein we found that at a minimum concentration of $3.12 \mathrm{mg} / \mathrm{ml}$, all periodontal pathogens were inhibited. ${ }^{[7]}$

Minimum inhibitory concentration of wheatgrass powder was found at $3.12 \mathrm{mg} / \mathrm{ml}$ for $\mathrm{Pg}$, whereas it was significantly lower for other organisms. Results support the inhibitory effect of wheatgrass powder on periodontal pathogens and application in vivo testing. Future therapeutic considerations might include alternating drugs, using different antimicrobials from one treatment to the next, as more drugs become available.
Although, traditionally, wheatgrass has been used for various disorders, till date, not much scientific literature is available on wheatgrass. It clearly signifies that a whole lot of scientific exploration needs to be done on this herb which could give the lead for natural alternative for diverse diseases against synthetic drugs. ${ }^{[8-10]}$

\section{CONCLUSIONS}

The present study provides preliminary evidence for the antimicrobial activity of wheatgrass powder against periodontal pathogens such as $\mathrm{Pg}, \mathrm{Pi}, \mathrm{Tf}$, and Fn. Traditional plants may represent new sources of antimicrobials, with wheatgrass showing maximum effect against periodontal pathogens at a minimum concentration of $3.12 \mathrm{mg} / \mathrm{ml}$. Wheatgrass shows a lot of promise in the field of alternative medicine, especially for applications in periodontitis and possibly other oral infections. Further studies are recommended for assessing its use both in clinical and field settings.

\section{REFERENCES}

1. Shewale AH, Gattani DR, Bhatia N, Mahajan R, Saravanan SP. Prevalence of periodontal disease in the general population of India a systematic review. J Clin Diagn Res 2016;10:ZE04-9.

2. Rana S, Kamboj JK, Gandhi V. Living life the natural way wheatgrass and health. Funct Foods Health Dis 2011;1:444-56.

3. Walters R. Options: The Alternative Cancer Therapy Book. Garden City Park, New York: Avery Publishing Group; 1993

4. Padalia S, Drabu S, Raheja I, Gupta A, Dhamija M. Multitude potential of wheatgrass juice (Green Blood): An overview. Chron Young Sci 2010;1:23-8.

5. Meyerowitz S. Sprout It. 1983.

6. Sundaresan A, Selvi A, Manonmani HK. The anti-microbial properties of Triticum aestivum (wheat grass) extract. Int J Biotech Wellness Ind 2015;4:84-91.

7. Rajpurohit L, Mehta N, Ankola AV, Gadiyar A. Evaluation of the anti-microbial activity of various concentration of wheat grass (Triticum aestivum) extract against Gram-positive bacteria: An in vitro study. J Dent Res Rev 2015;2:70.

8. Sareen M, Baghla P, Dhaka P, Mathur E, Sobti P, Khajuria S. Wheat grass a wonder herb. Syst Rev Pharm 2014;5:4-5.

9. Hattarki SA, Bogar C. Triticum aestivum (wheat grass); a power house plant-a review. Dent J Adv Stud 2017;5:25-9.

10. Shetty S, Thomas B, Shetty V, Bhandary R, Shetty RM. An in-vitro evaluation of the efficacy of garlic extract as an antimicrobial agent on periodontal pathogens: A microbiological study. Ayu 2013;34:445-51. 